\title{
Peptic ulcer disease: absence of antibodies stimulating the histamine sensitive adenylate cyclase of gastric mucosal cells
}

\author{
P Burman, S Mårdh, L Lööf, J Naesdal, F A Karlsson
}

\begin{abstract}
The possible presence of parietal cell stimulating antibodies was examined in sera from 57 patients with relapsing ulcer disease. The sera were obtained at the time of symptomatic relapse and all patients had ulcers confirmed by endoscopy. A sensitive assay based on adenosine $3^{\prime}: 5^{\prime}$ cyclic monophosphate (cAMP) production in isolated porcine gastric mucosal cells was used as a measure. cAMP production increased up to four hours of incubation and was histamine responsive; an approximately 20 -fold increase was found with histamine $10^{-4} \mathrm{~mol} / \mathrm{l}$. Sera from both patients and healthy control subjects showed some inhibitory effect on basal cAMP production compared with incubation in medium only, whereas immunoglobulin preparations had a weaker non-specific effect. No stimulation was found when the patients' sera and immunoglobulins (up to a concentration of $6 \mathrm{mg} / \mathrm{ml}$ ) were examined. These results suggest that gastric acid hypersecretion in duodenal ulcer disease is not an effect of histamine receptor stimulating antibodies. The data thus argue against a recent hypothesis that severe chronic ulcer disease in some patients has an autoimmune origin.
\end{abstract}

Peptic ulcer is a multifactorial disease that is not yet fully understood. Gastric acid is considered to be a major aggressive factor and gastric acid hypersection has been shown in patients with duodenal ulcer disease. ${ }^{1}$ A large parietal cell mass, ${ }^{2}$ enhanced sensitivity to pentagastrin, ${ }^{3}$ and increased gastrin secretion after meals have been reported in subgroups of patients. ${ }^{4}$ Besides the presence of gastric acid, an impairment of mucosal defense mechanisms may be of relevance in the development of ulcers. In several studies, smoking has been associated with an increased risk of relapse and slower ulcer healing rates. ${ }^{56}$ Smoking reduces pancreatic bicarbonate output ${ }^{7}$ and thereby causes a decrease in duodenal $\mathrm{pH}$. Furthermore, studies on intestinal mucosal blood flow in dogs have shown a negative effect of nicotine. ${ }^{8}$ Impaired bicarbonate secretion from the proximal duodenal mucosa at rest and in response to luminal acidification has been observed in patients with a history of duodenal ulcer disease. ${ }^{9}$ Chemical compounds such as aspirin and non-steroidal anti-inflammatory drugs have been associated with a high incidence of gastric ulcers as well as ulcer bleeding. ${ }^{10}$ More recently a causal relation between Helicobacter pylori and duodenal ulcer as well as gastritis has been proposed." This issue is under current debate and awaits confirmation.

It has been suggested that some forms of duodenal ulcer may be of immunological origin. ${ }^{12}$ Dobi and Lenkey ${ }^{13}$ reported in 1982 that immunoglobulins prepared from sera of patients with relapsing ulcers increased gastric acid secretion when injected into rats. Recently deLazarri et al claimed the existence of histamine receptor stimulating antibodies in 13 of 30 duodenal ulcer patients. ${ }^{14}$ In this study we established a sensitive assay for detection of parietal cell stimulation to explore this possibility.

\section{Methods}

PREPARATION OF PORCINE GASTRIC MUCOSAL AND PARIETAL CELLS

Gastric mucosal cell preparations containing 15$25 \%$ (mean $18 \%$ ) parietal cells were obtained from the corpus mucosa of porcine stomachs after treatment with pronase and collagenase. ${ }^{15}$

STIMULATION OF ADENOSINE $3^{\prime}: 5^{\prime}$ CYCLIC MONOPHOSPHATE (CAMP) PRODUCTION OF GASTRIC MUCOSAL CELLS

Porcine corpus mucosal cells were incubated at $+37^{\circ} \mathrm{C}$ in Eagle's medium with $20 \mathrm{mmol} / 1$ Hepes pH 7.4 and $0.5 \mathrm{mmol} / 1$ isobutylmethylxanthine in an atmosphere of $95 \% \mathrm{O}_{2} / 5 \% \mathrm{CO}_{2}$. In preliminary experiments, cAMP was detectable in media, but not in cell lysates, after 30 minutes of incubation in the presence of a phosphodiesterase inhibitor $(0.5 \mathrm{mmol} / 1$ isobutylmethylxanthine). We and others ${ }^{16}$ have obtained analogous results with respect to cAMP in experiments stimulating the adenylate cyclase of thyroid cells in culture. Initially, concentrations of mucosal cells up to $10 \times 10^{6} / \mathrm{ml}$ were used. A more appropriate concentration was later found to be about $2 \times 10^{6} / \mathrm{ml}$, and this concentration was used in experiments with patient immunoglobulins. After incubations with sera $(20 \% \mathrm{v} / \mathrm{v})$ or immunoglobulin preparations $(2 \cdot 4 \mathrm{mg} / \mathrm{ml}$ or 6.0 $\mathrm{mg} / \mathrm{ml}$ ) from patients and healthy subjects the mixtures were spun at $8000 \mathrm{~g}$ for 60 seconds. The cell pellets were discarded and the amount of cAMP in the supernatants was assayed with a radioimmunoassay kit (Rianen cyclic AMP ${ }^{125}$, Dupont). Submaximal and maximal stimulation with histamine $\left(10^{-6}\right.$ and $\left.10^{-4} \mathrm{M}\right)$ were determined in each separate run. The interassay coefficient 


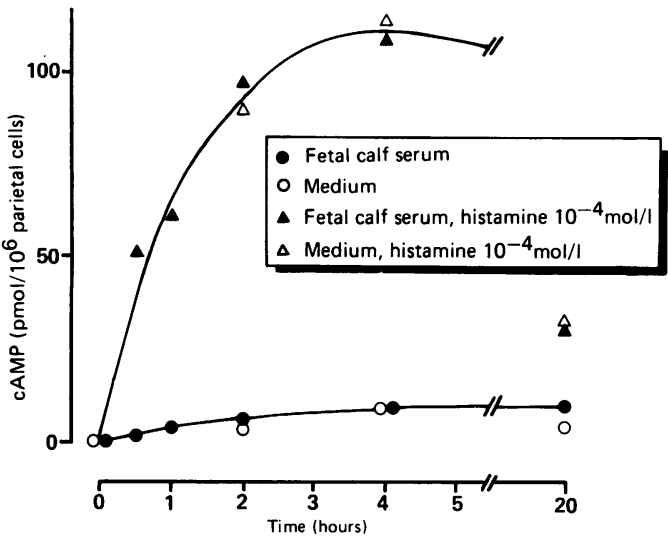

Figure 1: Time dependent adenosine $3^{\prime}: 5^{\prime}$ cyclic monophosphate (cAMP) production in porcine gastric mucosal cells. Cells, $5 \cdot 8 \times 10^{\circ} / \mathrm{ml}(20 \%$ parietal cells) were incubated at $37^{\circ}$ in Eagle's medium containing $0.5 \mathrm{mmol} / \mathrm{l}$ isobutylmethylxanthine with $20 \%$ fetal calf serum. Maximal cAMP production was estimated in the presence of $10^{-4}$ mol/l histamine. Reactions were stopped by centrifugation, see methods section. The results are expressed as the mean of duplicate incubations.

of variation, derived from six duplicates of basal cAMP production with $10^{6}$ parietal cells per ml was $18 \%$.

\section{IMMUNOGLOBULIN PREPARATIONS}

Immunoglobulins were precipitated from sera with $1.6 \mathrm{~mol} / \mathrm{l}$ ammonium sulphate, dialysed against Eagle's medium pH $7 \cdot 4$ and studied at a concentration of $2.4 \mathrm{mg} / \mathrm{ml}$. In subsequent experiments with higher concentrations of immunoglobulins, the precipitates were more extensively dialysed against Eagle's medium with $20 \mathrm{mmol} / 1 \mathrm{Hepes} \mathrm{pH} 7.4$ and $0.5 \mathrm{mmol} / \mathrm{l}$ isobutylmethylxanthine in order to minimise the non-specific inhibition of parietal cAMP formation. Final protein concentrations ranged between 14.6 and $25.5 \mathrm{mg} / \mathrm{ml}$, mean $19.8 \mathrm{mg} / \mathrm{ml}$, as assessed by the BioRad dye protein detection kit.

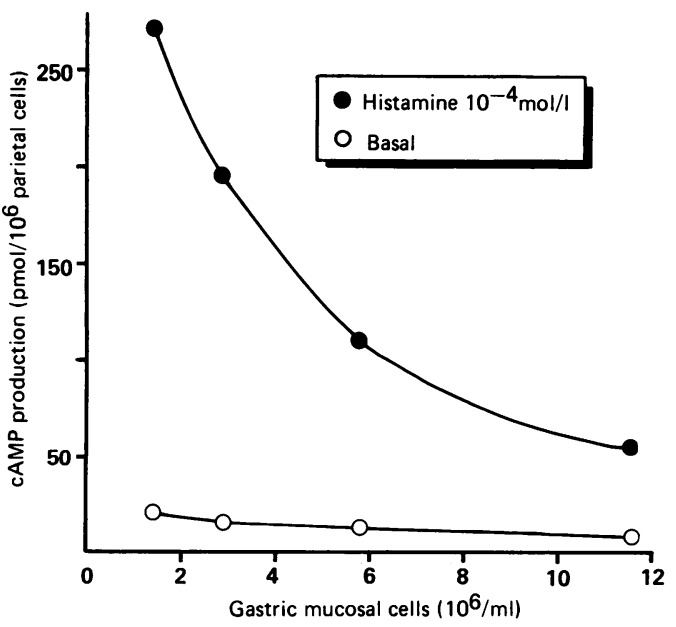

Figure 2: Effect of cell concentration on adenosine $3^{\prime}: 5^{\prime}$ cyclic monophosphate (cAMP) production in porcine gastric mucosal monophosphate (cAMP) production in porcine gastric mucosal
cells. Gastric mucosal cells (15\% parietal cells) at various concentrations were incubated for four hours and basal and maximal $\left(10^{-4}\right.$ mol/l) histamine stimulated cAMP release was tested as described in methods. The data represent mean of duplicate incubations.

\section{PATIENTS}

Fifty seven patients ( 31 men and 26 women) aged 20-78 years (mean 54 years) were included in the study. All but four patients had a history of relapsing ulcer disease for one to 30 years, mean 10.8 years. Two patients had earlier been treated for Graves' disease, another two were having thyroxine substitution treatment because of autoimmune thyroiditis, two had non-insulin dependent diabetes mellitus, two had hypertension, and two patients suffered from claudicatio intermittens. Thirty five of the patients were smokers, the majority of whom smoked $\geq 10$ cigarettes per day. The patients were referred from general practitioners, ward units, and outpatient clinics for endoscopy because of symptomatic ulcer relapse. Forty eight were found to have duodenal ulcers while nine had prepyloric ulcerations. Treatment was begun with either $\mathrm{H}_{2}$ receptor antagonists, omeprazole, or rioprostil. With regard to the outcome of the ulcer medication, the patients could be separated into two groups. In 25 patients, including the four with a first attack of ulcer disease, the ulcers healed in less than two months on daily doses of either $0.8 \mathrm{~g}$ cimetidine, $600 \mu \mathrm{g}$ rioprostil, or 40 mg omeprazole. In the remaining 32 patients there was a poor response to treatment. None of the ulcers healed after eight weeks on ranitidine $300 \mathrm{mg}$ daily or cimetidine $0 \cdot 8-1 \mathrm{~g}$ daily. In this group blood samples were taken within two months of an endoscopy showing an active ulcer. In the first group, in whom ulcers responded to treatment, serum samples were obtained at the time of the first endoscopy. Control sera were drawn from 24 healthy blood donors ( 14 men, 10 women; 22 to 65 years of age, mean 41 years).

\section{Results}

In the initial experiments we searched for conditions that would optimise the assay. cAMP in the media increased as a function of the incubation time and reached a plateau at about four hours (Fig 1). The cAMP production was stimulated by histamine. The response was negatively correlated to the cell concentration during the incubations, possibly by favouring anaerobic conditions or changes in $\mathrm{pH}$. Thus, with histamine $10^{-4} \mathrm{mmol} / 1$ and 2 or $10 \times 10^{6}$ cells $/ \mathrm{ml}$, 20 or sevenfold increases in cAMP were found, respectively. The observation was confirmed in a second set of experiments with various concentrations of cells (Fig 2). In further experiments, a four hour incubation period and cell concentrations at about $2 \times 10^{6} / \mathrm{ml}$ were used routinely. The effect of histamine was dose dependent (Fig 3). The stimulatory effect of histamine was reproducible and was confirmed with each cell preparation. In six consecutive experiments the response to histamine $10^{-6} \mathrm{~mol} / \mathrm{l}$ was $1 \cdot 6-2 \cdot 8$-fold $(2.29(0.21)$ mean (SEM)), while stimulation with histamine $10^{-4} \mathrm{~mol} / \mathrm{l}$ gave a 10 to 25 -fold $(18.5(2 \cdot 16))$ increase, and $10^{-3} \mathrm{~mol} / 1$ in two experiments gave $>25$-fold stimulation.

Sera from 17 ulcer patients were tested for their ability to stimulate cAMP production. No stimulation was found. By contrast, a $20 \%$ impairment compared with incubation in medium alone, was repeatedly observed. By 


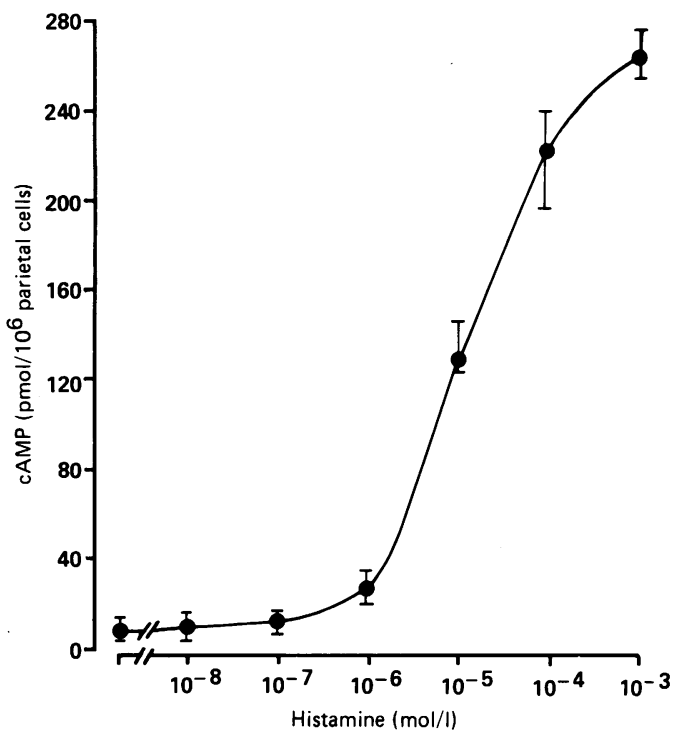

Figure 3: Histamine stimulated adenosine $3^{\prime}: 5^{\prime}$ cyclic monophosphate (cAMP) production in porcine gastric mucosal cells, $2.5 \times 10^{\circ} / \mathrm{ml}(18 \%$ parietal cells $)$ were incubated in 165 ul Eagle's medium $\mathrm{pH} 7.4$ with $0.5 \mathrm{mmol} / \mathrm{l}$

isobutylmethylxanthine at $37^{\circ} .15$ ul of histamine was added to final concentrations of $10^{-8}$ molll to $10^{-3}$ molll. Incubations were stopped after four hours by centrifugation and cAMP in the media assayed as described in methods. The results are expressed as mean and range of triplicates.

precipitating immunoglobulin fractions from sera this non-specific effect was reduced to about $10 \%$. In 33 patients with recurrent severe ulcer disease, immunoglobulins were incubated with gastric mucosal cells at a concentration of $6 \mathrm{mg} / \mathrm{ml}$. No stimulatory effect on the histamine receptors of the parietal cells could be shown (Fig 4). In another 10 patients, where the amounts of sera were limited, immunoglobulins tested at $2.4 \mathrm{mg} / \mathrm{ml}$, likewise, showed no stimulatory activity compared with controls. The effect of $10^{-4} \mathrm{~mol} / \mathrm{l}$ histamine was not blunted by the presence of either serum or immunoglobulin preparations from healthy controls.

\section{Discussion}

The parietal cell is stimulated to produce gastric acid via at least three types of receptors:

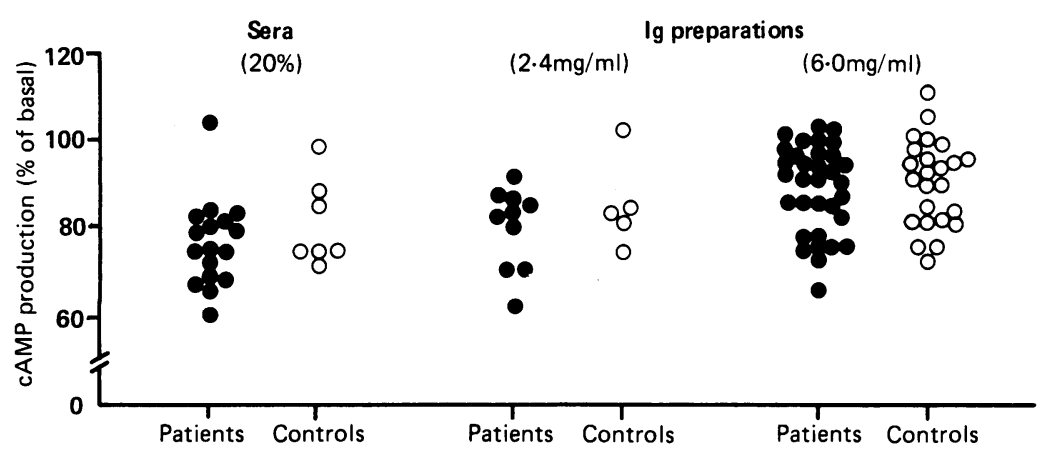

Figure 4: Effect of sera or immunoglobulin preparations from patients with active ulcer disease on adenosine $3^{\prime}: 5^{\prime}$ cyclic monophosphate (cAMP) production in porcine gastric mucosal cells. Cells $(15-22 \%$ parietal cells) were incubated in duplicates with and without additions for four hours. The CAMP concentration obtained in cultures exposed to medium alone was set as $100 \%$. A total of 57 patients were tested. Sera were employed in 17 cases and in three of these also immunoglobulins $(2.4 \mathrm{mg} / \mathrm{ml})$ were used. Immunoglobulins at $2.4 \mathrm{mg} / \mathrm{ml}$ were examined in another seven patients, and at $6.0 \mathrm{mg} / \mathrm{ml}$ in the remaining 33 cases, including all those with treatment resistant ulcers. Healthy blood donors served as controls. muscarinic, gastrin, and histamine. In vivo most of the gastrin stimulated acid secretion can be blocked by $\mathrm{H}_{2}$ receptor antagonists, indicating an action via a histamine stimulated pathway. ${ }^{17}$ The addition of histamine results in rising values of cAMP in the cell. ${ }^{18}$ In order to test the hypothesis that stimulatory antibodies could be responsible for non-regulated acid secretion in subgroups of patients, we adopted a sensitive in vitro system for analysis of cAMP in gastric mucosal cells. When sera or immunoglobulins in concentrations up to $6 \mathrm{mg} / \mathrm{ml}$ were used no stimulatory effect on the histamine receptor could be detected. This finding is in contrast with that of deLazarri et al, who reported stimulating immunoglobulins, tested at 2 and $4 \mathrm{mg} / \mathrm{ml}$, in 13 out of 30 cases. $^{14}$ With reference to severity, duration of disease, and response to treatment the patients in the two studies were comparable. The male:female ratio was $28: 2$ in their study and $31: 26$ in ours. However, the test systems do seem to differ both with respect to response to histamine (20-fold compared with fivefold cAMP increase with maximal stimulation) and to performance. In the study of deLazarri et al the nonspecific inhibition of cAMP production in the presence of immunoglobulin preparations was considerable, and basal cAMP accumulation was reported to vary up to 12 times in different cell preparations. Surprisingly, the relative incremental stimulation from basal values with such different stomachs were reported to show no statistical difference. In our study we attempted to optimise the assay to improve precision and obtained a histamine response better or similar to that described by others. ${ }^{19-23}$ We used porcine gastric mucosal cell preparations whereas deLazarri et al used guinea pig mucosa. Human autoantibodies in patients with various autoimmune disorders generally crossreact well with tissues of other species. For instance, rat tissues are routinely used in immunofluorescence tests for detection of antibodies against nuclei, smooth muscle, and parietal cells, ${ }^{2+}$ and in our experience, and that of others, ${ }^{16}$ thyroid stimulating hormone receptor autoantibodies are equally well detected with rat or porcine cells as with human cells. In our view, this excludes the possibility that the discrepancy between our study and that of deLazarri et al could be a result of the species differences in the experimental sources.

Dobi and Lenkey, ${ }^{13}$ by injections of immunoglobulins into rats, described gastric acid stimulatory immunoglobulins in 25 sera of 51 patients with duodenal ulcer. By the use of an indirect immunofluorescence technique the same preparations were found to bind to the parietal cells in sections of rat stomach. Binding could be abolished in the presence of cimetidine and it was concluded that the immunoglobulin was directed towards the $\mathrm{H}_{2}$ receptors. To our knowledge, sera from patients with duodenal ulcer disease do not usually stain parietal cells and reports of parietal cell antibodies in ulcer disease have not been published. Furthermore, hormone receptors such as thyroid stimulating hormone receptor or insulin receptor have not been visualised by immunofluorescent techniques in spite of having access to high titre patient antisera (unpublished). In our own investigations of 
antibodies against the parietal cell antigen, $\mathrm{H}^{+}, \mathrm{K}^{+}$-ATPase, we did not find autoantibodies in a group of 20 patients with duodenal ulcer disease. ${ }^{25}$ In this study, a membrane fraction of parietal cells was used as antigen in an enzyme linked immunosorbent assay.

In previous studies of risk factors for developing relapsing ulcer disease, an increased incidence of smoking, alcohol abuse, intake of analgesic drugs, and family history of peptic ulcer have been proposed. There is, however, no clinical association between severe ulcer disease and autoimmune endocrine disorders, such as Graves' disease, thyroiditis, and Addison's disease, all characterised by organ specific autoantibodies against cytoplasmic or membrane bound antigens. Neither is there an increased coexistence between the autoimmune disorder atrophic gastritis with pernicious anaemia and relapsing ulcers. ${ }^{26}$ Parietal cell antibodies are not found in an increased frequency in sera from patients with ulcer disease. ${ }^{25} 26$ Yet, deLazzari et al have suggested that ulcer disease is a new member of this group of autoimmune disorders. The results of the present study are not compatible with this hypothesis. Also, the known risk factors and the clinical characteristics of the patients argue against an autoimmune origin for duodenal ulcers. Although our study does not rule out the possibility of gastric stimulatory antibodies in exceptional cases, relapsing ulcer disease can not, in our view, be regarded as an organ specific autoimmune disorder.

We thank Thomas Björkman, Margareta Ericsson, and Majstin Lundberg for providing excellent assistance.

This study was supported by grants from the Medical Research Council (project no 4996, 4965), Swedish Society of Medicine Agnes and Mac Rudbergs Fund and 'Förenade Liv' Mutual Group Life Insurance Company, Stockholm, Sweden.

Part of these results were presented in abstract form at the American Gastroenterological Association Meeting, Washington, May 1989 .

1 Soll AH, Isenberg JI. Duodenal ulcer disease. In: Sleisenger MH, Fordtran JS, eds. Gastrointestinal disease: pathophysiology, diagnosis and management. 3rd edition. Philaphysiology, diagnosis and management.

$2 \mathrm{Cox}$ AJ, Stomach size and its relation to chronic peptic ulcer. Arch Pathol 1952; 54: 407-22.

3 Isenberg JJI, Grossman MI, Maxwell V, Walsh JH. Increased sensitivity to stimulation of acid secretion by pentagastrin in duodenal ulcer. $\mathcal{F}$ Clin Invest 1975; 55: 330-7.

4 Fritsch WP, Hausaman TU, Rick W. Gastric and extragastric gastrin release in normal subjects, in duodenal ulcer patients, and in patients with partial gastrectomy (Billroth I). Gastroenterology 1976; 71: 552-7.

5 Korman MG, Hansky J, Eaves ER, Schmidt GT. Influence of smoking on healing and relapse in duodenal ulcer disease. Gastroenterology 1983; 86: 871-4.

6 Sontag S, Graham D, Becsito A, et al. Cimetidine, cigarette smoking and recurrence of duodenal ulcer. $N$ Engl f Med 1984; 311: 689-93.

7 Bynum TE, Solomon TE, Johnson LR, Jacobsen ED. Inhibition of pancreatic secretion in man by cigarette smoking. Gut 1972; 13: 361-5.

8 Gallavan RH Jr, Tsuchiya Y, Jacobsen ED. Effects of nicotine on canine intestinal blood flow and oxygen consumption. Am $\mathcal{F}$ Physiol 1984; 246: G195-203.

9 Isenberg JI, Selling JA, Hogan DL, Koss MA. Impaired proximal duodenal mucosal bicarbonate secretion in patient with duodenal ulcers. N Engl F Med 1987; 316: 374-9.

10 Somerville K, Faulkner G, Langman $M$. Non-steroidal antiinflammatory drugs and bleeding peptic ulcer. Lancet 1986 i: $462-4$.

11 Hornick RB. Peptic ulcer disease: a bacterial infection? NEngl f Med 1987; 316: 1598-600.

12 Rotter JI, Heiner DC. Are there immunologic forms of duodenal ulcer? F Clin Lab Immunol 1982; 7: 1-6.

13 Dobi S, Lenkey B. Role of a secretagogue immunoglobulin in gastric acid secretion. Acta Med Acad Sci Hung 1982; 60: 9gastric.

14 DeLazzari F, Mirakian R, Hammond L, Venturi C, Naccarato R, Bottazzo GF. Gastric cell c-AMP stimulating autoantibodies in duodenal ulcer disease. Gut 1988; 29: 94-100

15 Mårdh S, Norberg L, Ljungström M, Humble E, Borg $T$, Carlsson C. Preparation of cells from pig gastric mucosa. Isolations of parietal cells by isopycnic centrifugation on linear density gradients of Percoll. Acta Physiol Scand 1984 122: $607-13$.

16 Kasagi K, Konishi J, Arai K, Misaki T, Llda Y, Endo K, Torizuka K. A sensitive and practical assay for thyroidstimulating antibodies using crude immunoglobulin frimulating antibodies using crude immunoglobulin fractions precipitated with polyethyl

17 Malinovska DH, Sachs G. Cellular mechanisms of acid secretion. Clin Gastroenterol 1984; 13: 309-26.

18 Soll AH, Berlindh T. Physiology of isolated gastric glands and parietal cells: receptors and effectors regulating functions In: Johnson LR, ed. Physiology of gastrointestinal tract 2nd edition. New York: Raven Press, 1987: 883-909.

19 Wollin A, Soll AH, Samloff IM. Actions of histamine secretin, and PGE 2 on cyclic AMP production by isolated canine fundic mucosal cells. Am F P hysiol 1979; 237: E43743.

20 Soll AH, Wollin A. Histamine and cyclic AMP in isolated canine parietal cells. Am f P hysiol 1979; 237: E444-50.

21 Batzri S, Gardner JD. Cellular cyclic AMP in dispersed mucosal cells from guinea pig stomach. Biochim Biophys Acta 1978; 541: 181-9.

22 Chew CS, Hersey SJ, Sachs G. Berglindh T. Histamine responsiveness of isolated gastric glands. Am F P hysiol 1980 238: G312-20.

23 Holian O, Ruiz C, Bombeck CT, Nyhus LM. Comparison of cAMP system in parietal cells from rat and guinea pig. Scand f Gastroenterol 1983; 16: 819-24.

24 Zweiman B, Lisak RP. Autoantibodies: autoimmunity and immune complexes. In: Todd I, Sanford M, Davidsohn R, Henry JB, eds. Clinical diagnosis and management by laboratory methods. Philadelphia: WB Saunders Company, 1984: tory method

25 Karlsson FA, Burman P, Lööf L, Olsson M, Scheynius A Mårdh S. Enzyme-linked immunosorbent assay of $\mathrm{H}^{+}, \mathrm{K}^{+}$ ATPase, the parietal cell antigen. Clin Exp Immunol 1987 70: 604-10

26 Ungar B, Francis CM, Cowling DC. Antibody to parietal cells in patients with duodenal ulcer, and relationship to pernicious anemia. Med F Aust 1976; 2: 900-2. 